\title{
Reviews
}

\section{Katja Lembke, Ammoniaca II, Das Grab des Siamun in der Oase Siwa, Mit Beiträgen von Heinz Felber und Jan Moje, Unter Mitarbeit von Michael Sohn (Zeichnungen) und Mohammed alRoumi (Photos) ArchäologischeVeröffentlichungen 115(Wiesbaden, 2014), 117 S., 24 Tafeln, ISBN 9783447102391}

The focus of this review is placed on the publication of the Old Egyptian tomb of Siamun from the oasis of Siwa. The content of the book under consideration can be analyzed in the following manner:

The book commences with abbreviations (911) and bibliograpy (1316).

In the introduction, some general information IS provided. A short catalogue of previous research is drawn up. The earliest mentioning of the Gebel elMota/Qaret al Missabbarin in modern travel literature can be found 1792 by W. G. Browne (17). The first hint at the decoration of the tombs was given 1826 by F. Cailliaud (17). The first meticulous archeological investigation of the oasis was conducted 1938 and 1941 by A. Fakhry (18). The tombs of the necropolis can all be assigned to the Ptolemaicroman time (20). The position and architecture of the tomb of Siamun are described, which is located at the western side of the plateau north of the mountain (20). The access to the monument of Siamun is gained by a six stepped staircase, which is - like the tomb - oriented from north to south with a deviation of 10 degree to the east (20). The tomb consists of a single long room, the length of which measures between 954 und $970 \mathrm{~cm}$ and breadth $260 \mathrm{~cm}$ (20). The area behind the southern wall, today mostly destroyed, is occupied by a nearly quadratic chamber A, in which the original main interment was made (20). The view of the side chambers BL having been used for secondary burials is advocated (20). The polychromic spectrum and preservation state of the paintings are given a detailed examination. The basic colour spectrum of the tomb consists of reddish-brown, green, and dark blue, being complemented by turquoise, light blue, cinnabar, pink, ochre, dark brown and black (22). The extraordinary use of cinnabar for the skin of the son of the tomb owner is touched on (23). The special feature of applying colours in al secco technique is highlighted (23). The case is made for the interpretation of the empty script bands in the uncompleted part of the tomb as index for a strict distinction between artists and scribes responsible for the decoration of the tomb (24). The paintings seem to have been executed from north to south (24).

In 2. Part A some space is devoted to the description of the scenes and translation of the inscriptions. The measures and preservation state are traced in a reasonable fashion. In the short commentary, the most important philological details are stressed (2539). The hitherto singular attestation for the office of the nekrostolistes in the tomb of Siamun is underlined, the activities of which are related to the mummification process (30). The one and only unusual late writing is represented by the "goose" for the preposition " $\mathrm{n}$ " "for" to be found on the western wall (37).

\section{Stefan Bojowald}

Ägyptologisches Seminar, Universität Bonn stefan.bojowald@tonline.de

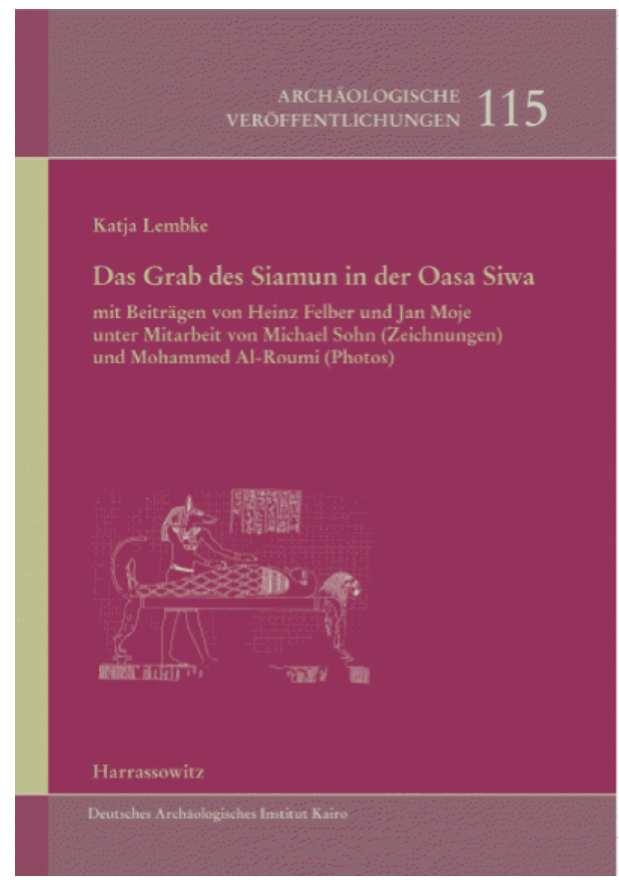

DOI: $10.14795 /$ j.v4i3.279

ISSN 2360 - 266X

ISSN-L 2360 - 266X 
In 3 Part B the analysis is conducted. In comparison with other architectural structures of the Gebel el Mota, a broader approach to the tomb of Siamun is embraced. The buildings are subdivided into two groups: a) instalments carved horizontally into the mountain, b) tombs dug on an incline in the northern plateau (41). The tomb of Siamun does actually adhere to the first group (41). In the necropolis, the tombs can be roughly split up into four types: 1) long facing one chamber tombs with staircases, main burials opposite the entrance, secondary burials in side walls, 2) entrance in the north, passageway with loculi in side walls, passages, shallowly vaulted chapel, second vaulted chapel, ambulatory around the chapel, backward tomb chamber, 3) porch with entrance corridor and open courtyard, rock complex with antechamber with secondary burial and chamber with main burial in the south, passage to undecorated chamber, main burial opposite entrance, 4) tombs with little shafts (4142). The division of the rock tomb with one single chamber and annexes on its sides can be detected already in the 26th dynasty at the oasis Bahrija (42). Staircases descending into the tomb arise already in Thebes of the New Kingdom (44). The preparation of the loculi before the decoration of the side walls can be compared with the early Hellenistic hypogeum A in Schiatbi (44). The decoration shows the following main themes: northern wall below the door guardians and northern area of the eastern wall: funerary procession; eastern wall: journey of the deceased through the underworld and transformation to Osiris; western wall: judgement of the dead, mummification and opening of the mouth (45). The ceiling in the front part is adorned with the goddess Nut and boats as symbol for the course of the sun, while the rear is stuffed with alternating vultures and hawks (45). The decoration of the walls and ceiling betrays Greec influence like the representation of the tomb owner as living person with locks and beard or an older man with a youth standing before him and stretching out a hand to his knee (47). In ancient Egyptian art, only two parallels for the last gesture are known, dating from the 4th dynasty and Amarna period, respectively (50). The tomb of Petoris in Tuna el-Gebel from the late 4th century BC is adduced as prime example for the fusion of the Graeco-Roman elements and Egyptian traditions (51). The tomb of Siamun heralds a certain development which leads from the integration of the tomb owner as historical person in an Egyptian tale structure to a standalone, Roman influenced representation (53). The picture of a protective vulture hovering above the tomb owner in $\mathrm{O} 3$ is understood as adoption of a motif from the royal iconographical repertory for the private sphere (53). The light skin colour of the men in the tomb of Siamun is interpreted as hint at a younger style change (57). The characteristics of the inscriptions, e. g. loss of eugraphy, replacement of signs, and missing words, are seen as hint at a scarse scribal competence (58). The reading of the name of the father of Siamun is corrected from "priw.w" to "hri.w" (59). The arrangement of the vertical text lines as columns of shorter lines is judged as indicative to a possible date from the Roman period (60). The investigation of the paleography is executed, the details of the signs being assessed as indication to a local tradition (68). The tomb owner is portrayed in the front part of the tomb as historic person und in the rear as transfigured one (87). The depiction as historic person, but with Egyptian clothes and integration in an Egyptian tale structure may suggest a date at the beginning of the Roman Empire (88). Greek elements such as egg staff and "Running Dog" have sept into the loculus decoration.

In the $4^{\text {th }}$ part, a catalogue of the painting fragments is prepared. The more than 1,000 fragments are classified in a) loculus-decorations, b) figural representations, c) hieroglyphs, d) furniture and tools, e) offering table, and f) ornaments (91). The fragments are introduced with measurements and short description.

The book is terminated with the plates (124), offering black-and-white as well as coloured photographs.

The reviewer arrives at the following conclusion: The details of the tomb are well assembled and presented lucidly. The arguments put forward make a balanced impression. The reader is indebted to the authors for the amount of data provided. 